\title{
CONSERVATION OF 'TOMMY ATKINS' MANGOES STORED UNDER PASSIVE MODIFIED ATMOSPHERE ${ }^{1}$
}

\author{
JOSENARA DAIANE DE SOUZA COSTA ${ }^{2 *}$, ACÁCIO FIGUEIREDO NETO ${ }^{3}$, FRANCISCO DE ASSIS CARDOSO \\ ALMEIDA $^{2}$, MARYLIA DE SOUSA COSTA ${ }^{2}$
}

\begin{abstract}
For climacteric fruits, such as mango, losses have been reported from harvest to fruit consumption. Thus, controlled refrigeration and passive modified atmosphere have been used in combination with edible and biodegradable coatings or plastic packaging to minimise these losses. The present study aimed to evaluate the influence of carnauba wax and Xtend plastic packaging film, with and without refrigerated storage, on the post-harvest preservation of 'Tommy Atkins' mangoes. The fruits were coated with carnauba wax and/or wrapped in Xtend bags and then stored at $12 \pm 1$ and $25 \pm 3{ }^{\circ} \mathrm{C}$ for 21 days. The weight loss, fruit firmness, total soluble solids, titratable acidity, vitamin $\mathrm{C}$ content, and the $\mathrm{CO}_{2}$ concentration inside the package were determined at 7-day intervals. Cold storage was observed to slow down the rate of degradation and to reduce adverse degradation reactions. By coating the fruits with carnauba wax, packaging them with Xtend plastic and keeping them under refrigeration, it was possible to store the mangoes at $12 \pm 1{ }^{\circ} \mathrm{C}$ for 21 days. In this way, the $\mathrm{CO}_{2}$ concentration was reduced, mass loss and acidity were decreased, and the fruit firmness was preserved.
\end{abstract}

Keywords: Mangifera indica L.. Carnauba wax. Plastic packaging.

\section{CONSERVAÇÃO DE MANGAS 'TOMMY ATKINS' ARMAZENADAS EM ATMOSFERA MODIFICADA PASSIVA}

RESUMO - Em frutos climatéricos, como é o caso da manga, as perdas vão da colheita ao consumo. Tendo como controle a refrigeração e a modificação da atmosfera passivamente, com emprego de revestimentos comestíveis e biodegradáveis ou o acondicionamento em filmes plásticos. Objetivou-se avaliar a influência da cera de carnaúba e embalagem de filme plástico Xtend, utilizando ou não refrigeração na conservação póscolheita de manga 'Tommy Atkins'. Os frutos foram revestidos com solução de cera de carnaúba e/ou acondicionados nas embalagens Xtend e armazenados nas temperaturas de $25 \pm 3{ }^{\circ} \mathrm{C}$ e $12 \pm 1{ }^{\circ} \mathrm{C}$, por 21 dias. A cada sete dias foram realizadas avaliações quanto à perda de massa, firmeza do fruto, sólidos solúveis totais, acidez total titulável e vitamina $\mathrm{C}$ dos frutos e concentração de $\mathrm{CO}_{2}$ nas embalagens. Verificou-se que o armazenamento refrigerado retardou a velocidade das reações de degradação, auxiliando na conservação de mangas 'Tommy Atkins'. O revestimento dos frutos com cera de carnaúba e embalagem Xtend, sob refrigeração, possibilitou o seu armazenamento por 21 dias a $12 \pm 1{ }^{\circ} \mathrm{C}$, reduzindo a concentração de $\mathrm{CO}_{2}$, a perda de massa e a diminuição da acidez dos frutos e preservando a firmeza.

Palavras-chave: Mangifera indica L.. Cera de carnaúba. Embalagem de filme plástico.

\footnotetext{
"Corresponding author

${ }^{1}$ Received for publication in 08/16/2016; accepted in 03/15/2017.

Extracted from the first author's Master's dissertation, funded by CAPES

${ }^{2}$ Department of Agricultural Engineering, Universidade Federal de Campina Grande, Campina Grande, PB, Brazil; josenara.costa@gmail.com, cardoso.almeida@ufcg.edu.br, marylia.sousacosta@gmail.com.

${ }^{3}$ College Academic of Environmental an Agricultural Engineering, Universidade Federal do Vale do São Francisco, Juazeiro, BA, Brazil; acacio.figueiredo@univasf.edu.br.
} 


\section{INTRODUCTION}

Mangoes are of great economic importance to the international market, However, a reduction in post-harvest losses represents an enormous challenge for Brazilian growers. Such losses result from biochemical processes and physiological deterioration that occur during ripening. These losses undermine the visual appearance of the fruit, thereby, decreasing the product market value (BRITO et al., 2013). Various strategies exist to minimise the postharvest losses. For instance, cold storage is a simple technique that aims to extend the fruit shelf life and expand both trade and transport time.

The use of a complementary technique, such as modified atmosphere packaging and the use of a biodegradable coating, also helps to hinder the degradation processes (AMARIZ et al., 2010), thus, preserving the product quality between harvest and consumption. Edible coatings are an increasingly studied alternative, commonly used for fruit preservation. Edible coatings aid to preserve fruit colour, texture and nutritional value, while simultaneously decreasing gas exchange and water loss or excessive water gain (ASSIS; BRITTO, 2014). Carnauba wax is a natural, easily removable, non-toxic substance that is highly effective in fruit preservation. Besides presenting no time restriction as to its use, carnauba wax reduces moisture losses and provides gloss (MOTA et al., 2012; SERPA et al., 2014).

Fruit preservation, through passive control of the atmosphere composition, can also be obtained by using suitable packaging. Gas concentration in the containers varies with time, temperature, respiration and product permeability (JERONIMO et al., 2007). Films, for example, have been developed and used to preserve a variety of fruits. Xtend films remove excess moisture and reduce excessive respiration issues.

The study of alternative materials that work together with temperature is most important for the control of fruit ripening and for minimising fruit quality losses. Fruit quality loss can also be prevented by observing an ideal storage time, helping to place the product on the market. Consequently, the aim of the present study was to assess the conservation of 'Tommy Atkins' mangoes, stored under modified atmosphere with carnauba wax and Xtend plastic film packaging, with and without refrigeration.

\section{MATERIAL AND METHODS}

The 'Tommy Atkins' mangoes used in the experiment were obtained from a commercial orchard belonging to the Special Fruit Import \& Export Ltd. farm, located in the city of
Juazeiro - Bahia. The farm lies at $9^{\circ} 24^{\prime} 45.85^{\prime \prime} \mathrm{S}$ and $40^{\circ} 30^{\prime} 53.51^{\prime \prime} \mathrm{W}$ at an altitude of $374 \mathrm{~m}$, and has an annual average temperature of $26.7^{\circ} \mathrm{C}$.

The fruits were harvested in May 2015 at stage 2 of maturation (external appearance of the fruit being $75 \%$ green and $25 \%$ purple). The fruits were transported from the farm to the packing house, where they were washed and pre-selected, considering their stage of ripeness, colour, size, uniformity, mass, and absence of injuries or diseases. The fruits were ultimately packed in plastic boxes. Then they were transported to the laboratory, where they were individually washed in tap water, and immersed in a solution of $150 \mathrm{mg}$ chlorine per litre of water for $15 \mathrm{~min}$. They were rinsed to remove excess chlorine and then dried at room temperature.

The mangoes were separated into four batches of 32 fruits. They were then submitted to the following processes: application of commercial carnauba wax (C); wrapping in flexible Xtend ${ }^{\circledR}$ 885-MN1 packaging (E), $28 \mu \mathrm{m}$ thick, $3.5 \times 10^{-10} \mathrm{~cm}^{2} \cdot \mathrm{s}^{-1} \quad \mathrm{O}_{2}$ diffusivity and $5.3 \times 10^{-10} \mathrm{~cm}^{2} . \mathrm{s}^{-1} \mathrm{CO}_{2}$ diffusivity; a combination of carnauba wax and Xtend packaging $(\mathrm{C}+\mathrm{E})$, and a control (CT), where the fruits were sanitised only.

The carnauba wax solution was obtained by diluting commercial wax (Tropical 2055) at a 3: 1 ratio $\left(\mathrm{V}_{\text {water }}: \mathrm{V}_{\text {wax }}\right)$. The fruits remained immersed in the suspension for $1 \mathrm{~min}$, then they were drained by using a metal sieve and placed on a bench to dry naturally.

The fruits were distributed in batches of eight into cardboard boxes $(350 \times 285 \times 105 \mathrm{~mm})$, and two 21-day storage conditions were assessed including (1) in a biochemical oxygen demand (BOD) chamber at $12 \pm 1{ }^{\circ} \mathrm{C}$ and $58 \pm 2 \%$ relative humidity (RH), and (2) on a laboratory bench at ambient temperature $\left(25 \pm 3{ }^{\circ} \mathrm{C}\right)$ and $\mathrm{RH}(68 \pm 4 \%)$. Evaluations were performed at 7-day intervals.

The mass loss (\%) was calculated by using a semi-analytical scale with an accuracy of $0.01 \mathrm{~g}$. Fruit firmness $(\mathrm{N})$ was determined using a digital penetrometer (model PTR 300), with a 5-mm nozzle diameter. Fruit readings were taken at an equatorial position.

A digital refractometer with automatic temperature compensation (Invert Sugar Refractometer HI 96804) was used to determine the total soluble solids (TSS), which were expressed as ${ }^{\circ}$ Brix. The titratable acidity (TA) was obtained by titrating the sample with a sodium hydroxide solution $(0.1 \mathrm{M} \quad \mathrm{NaOH})$ and using $1 \%$ phenolphthalein as the indicator, according to the method of the Instituto Adolfo Lutz (IAL, 2008). The results were presented as a percentage of citric acid. Vitamin $\mathrm{C}$ content was determined by titration using 0.02\% 2,6-dichloro-phenol-indophenol (DCFI) solution, according to Strohecker and Henning (1967). The results were expressed as mg of ascorbic acid per $100 \mathrm{~g}$ of pulp. 
Carbon dioxide $\left(\mathrm{CO}_{2}\right)$ concentration was determined using a Shimadzu GC-2014 gas chromatograph, equipped with an electron capture detector and an Agilent Technologies HP-5 capillary column. The injector and detector temperatures were 280 and $300{ }^{\circ} \mathrm{C}$, respectively. Samples of the atmosphere were collected from the Xtend packaging, each containing two fruits. The post-harvest techniques, $\mathrm{E}$ and $\mathrm{C}+\mathrm{E}\left(25 \pm 1^{\circ} \mathrm{C}\right.$ and $12 \pm 1{ }^{\circ} \mathrm{C}$ ), were also evaluated, by analysing samples $(20 \mathrm{ml})$ of the gaseous atmospheres collected from each package via a hypodermic syringe. The results were expressed as a percentage $(\%)$, showing the mean and standard deviation for each day of analysis.

The experimental design was completely randomised, with four replications of one fruit, and a $4 \times 2 \times 4$ factorial design, corresponding to the four techniques (CT, $\mathrm{C}, \mathrm{E}$ and $\mathrm{C}+\mathrm{E}$ ), two storage temperatures $\left(12 \pm 1\right.$ and $\left.25 \pm 1{ }^{\circ} \mathrm{C}\right)$ and four storage periods $(0,7,14$ and 21 days). The data were examined by analysis of variance, using Tukey's test at $5 \%$ probability, and regression at 1 and $5 \%$ probability. Assistat software, version 7.7 beta was used (SILVA, 2014).

\section{RESULTS AND DISCUSSION}

By analysing the interaction between the technique and storage time, it was found that for all techniques, the mass loss increased during storage (Figure 1A), confirming that the fruits, whether coated and/or packaged, continued to respire and undergo metabolic processes, post-harvest (SANTOS et al., 2011a). However, the use of a modified atmosphere, achieved by carnauba wax combined with Xtend packaging, increased the humidity around the fruit, thereby, reducing the water movement from the product to the environment through existing surface pores (GUADARRAMA; PEÑA, 2013). This would decrease the loss of fresh mass and would contribute towards an increase in external fruit quality.
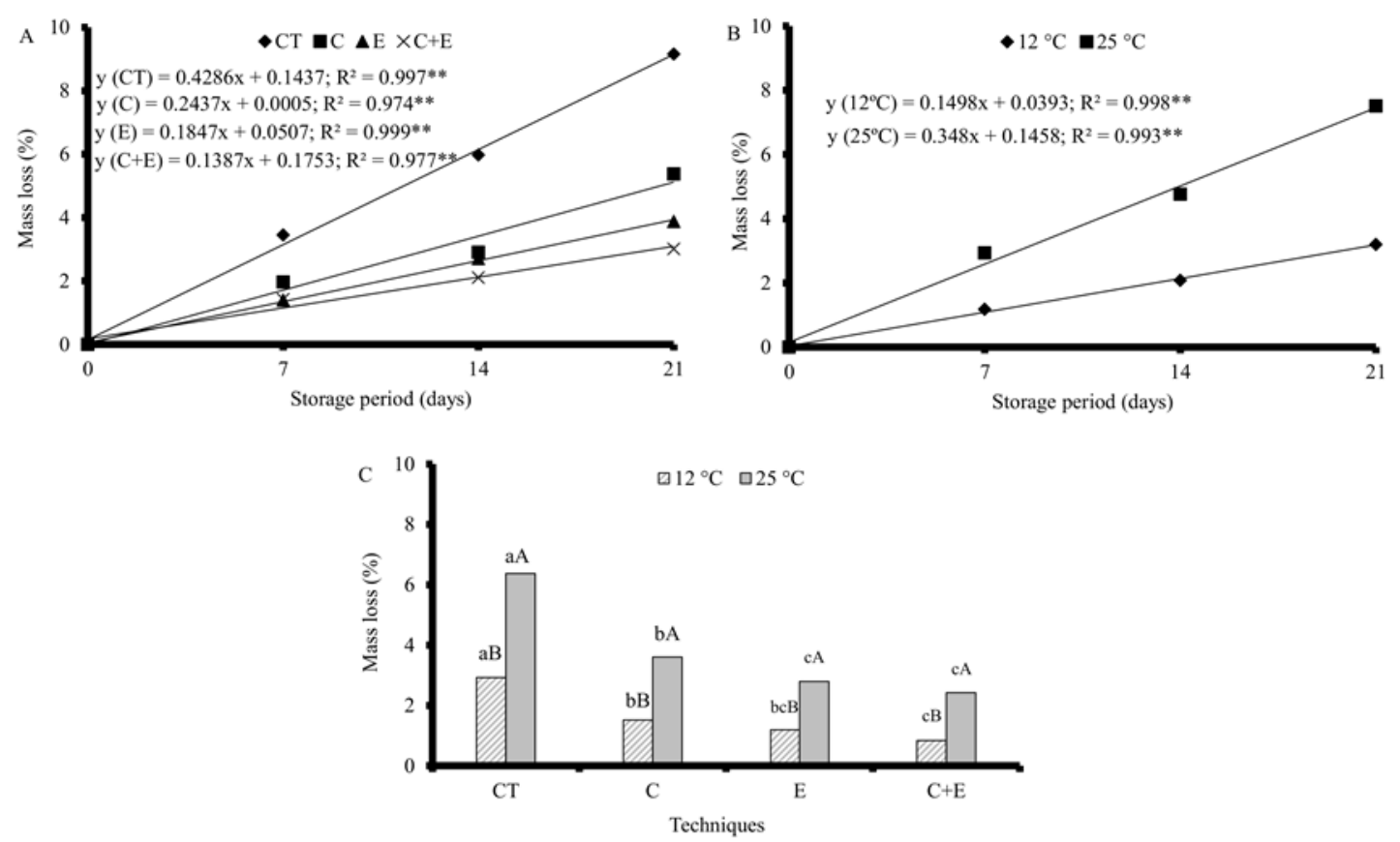

Figure 1. Influence of interaction between the technique and storage duration (A), storage temperature and storage duration (B), and technique and storage temperature (C) on the mass loss of 'Tommy Atkins' mangoes. CT - control; C - carnauba wax; E - Xtend packaging; C + E - carnauba wax and Xtend packaging. Bars with the same capital letter in the technique at different storage temperatures do not differ by Tukey's test at $5 \%$ probability.

From day 14, the fruits in the control group presented a weight loss above 5\%, which may compromise the fruit consistency, promote wrinkling, wilt and reduce the fruit shelf life. Moreover, when stored at $25{ }^{\circ} \mathrm{C}$ for 7 days, the fruit became unfit for commercialisation due to deterioration. Cordeiro et al. (2014) reported that the ripening of mangoes at room temperature advances rapidly, such that mango quality lasts a maximum of 8 days, due to its high perishability.
In Figures $1 \mathrm{~B}$ and $1 \mathrm{C}$, it is observed that regardless of the technique used, the fruits kept under refrigeration $\left(12{ }^{\circ} \mathrm{C}\right)$ exhibited much lower weight loss than those stored at $25^{\circ} \mathrm{C}$, which demonstrates that the difference depended not only on the packaging and/or coating used but also on the storage temperature. Miguel et al. (2013) evaluated the quality of 'Palmer' mangoes stored at various temperatures and found that the fruits can be refrigerated at $12{ }^{\circ} \mathrm{C}$ for 21 days, with no damage to 
ripening.

Figure $1 \mathrm{C}$ shows that the combination of refrigeration, carnauba wax coating and Xtend packaging $(\mathrm{C}+\mathrm{E})$ is the best strategy towards the preservation of fresh 'Tommy Atkins' mango mass during storage; because weight loss was observed to be 3.35 times lower than the control. Similarly, Yamashita et al. (2001), evaluating the storage of 'Tommy Atkins' mangoes packaged with polyvinyl chloride films at $12{ }^{\circ} \mathrm{C}$, observed that fruit weight was 3.5 times higher than that found in the control fruits. Also, Pinto et al. (2006) found that packaging with plastic film Xtend, was effective in 'Golden' papaya preservation, with mass losses of $5.58 \%$ for the control fruit and $3.52 \%$ for the packaged fruits after 21 days cold storage $\left(10{ }^{\circ} \mathrm{C}\right)$.

Fruit firmness decreased as the storage period advanced but was also influenced by the techniques and storage temperatures used (Figures 2A and 2B). The fruits coated with wax or packaged in Xtend did not differ from the control fruits, which had an initial firmness of $155.43 \mathrm{~N}$ when picked but this had decreased to $28.28 \mathrm{~N}, 21$ days later. A decrease in fruit firmness occurs as a result of the cell wall carbohydrate metabolism, following an increase in the enzymatic activity associated with other processes, such as starch hydrolysis and mass loss, which cause the fruit to soften during maturation (VILAS BOAS et al., 2004).

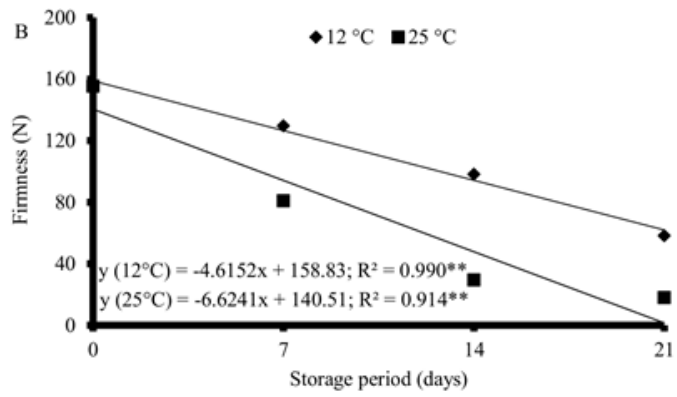

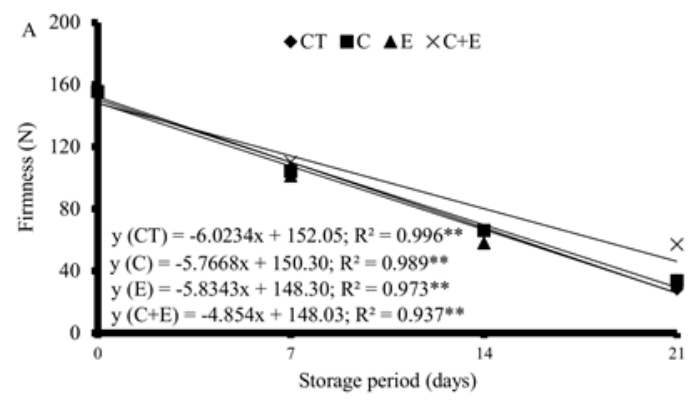

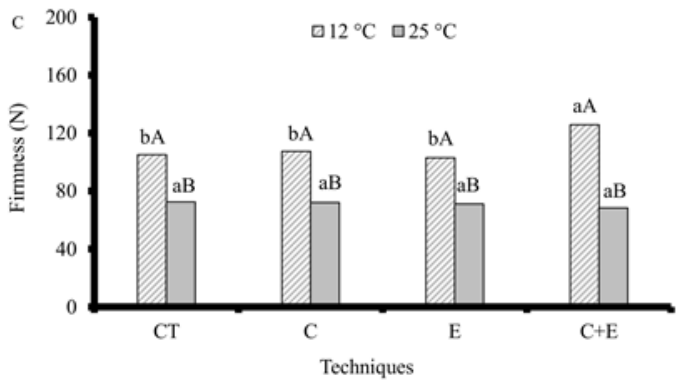

Figure 2. Influence of the interaction between the technique and storage duration (A), storage temperature and storage duration (B), and technique and storage temperature (C) on the firmness of 'Tommy Atkins' mangoes. CT - control; $\mathrm{C}$ - carnauba wax; E - Xtend packaging; C + E - carnauba wax and Xtend packaging. Bars with the same capital letter in the techniques at different temperatures do not differ by Tukey's test at $5 \%$ probability.

At $25{ }^{\circ} \mathrm{C}$, the techniques did not prove effective in reducing fruit firmness (Figure 2C). Conversely, when stored at $12{ }^{\circ} \mathrm{C}$, the mangoes coated with carnauba wax and packaged in Xtend plastic film $(\mathrm{C}+\mathrm{E})$ showed a decrease in the cell wall degradation, exhibiting, as a result, far superior firmness $(97.19 \mathrm{~N})$, when compared with the CT, C and $\mathrm{E}$ fruits. Consequently, among the various treatments studied, treatment $\mathrm{C}+\mathrm{E}$ proved most efficient in maintaining fruit integrity, thereby, providing less fragile fruit for transportation, and promoting a longer shelf life.

The post-harvest techniques caused a slower increase in the TSS than that observed in the control fruits, whereby the increase followed a quadratic equation, with a significant development during the first 7 days of storage (Figure 3A). These differences represent natural processes that occur during the ripening of the fruit. As observed by Jha, Kingsly and Chopra (2006), two distinct phases in the TSS exist. During maturation, there is a slight increase in the TSS, with no systematic trend. After fruit maturity, however, the TSS increases significantly. In most fruits, this is due to the biosynthesis or breakdown of substances, such as starch, with its subsequent transformation into soluble sugars, and the loss of weight, which increases the soluble solids concentration (CHITARRA; CHITARRA, 2005). 

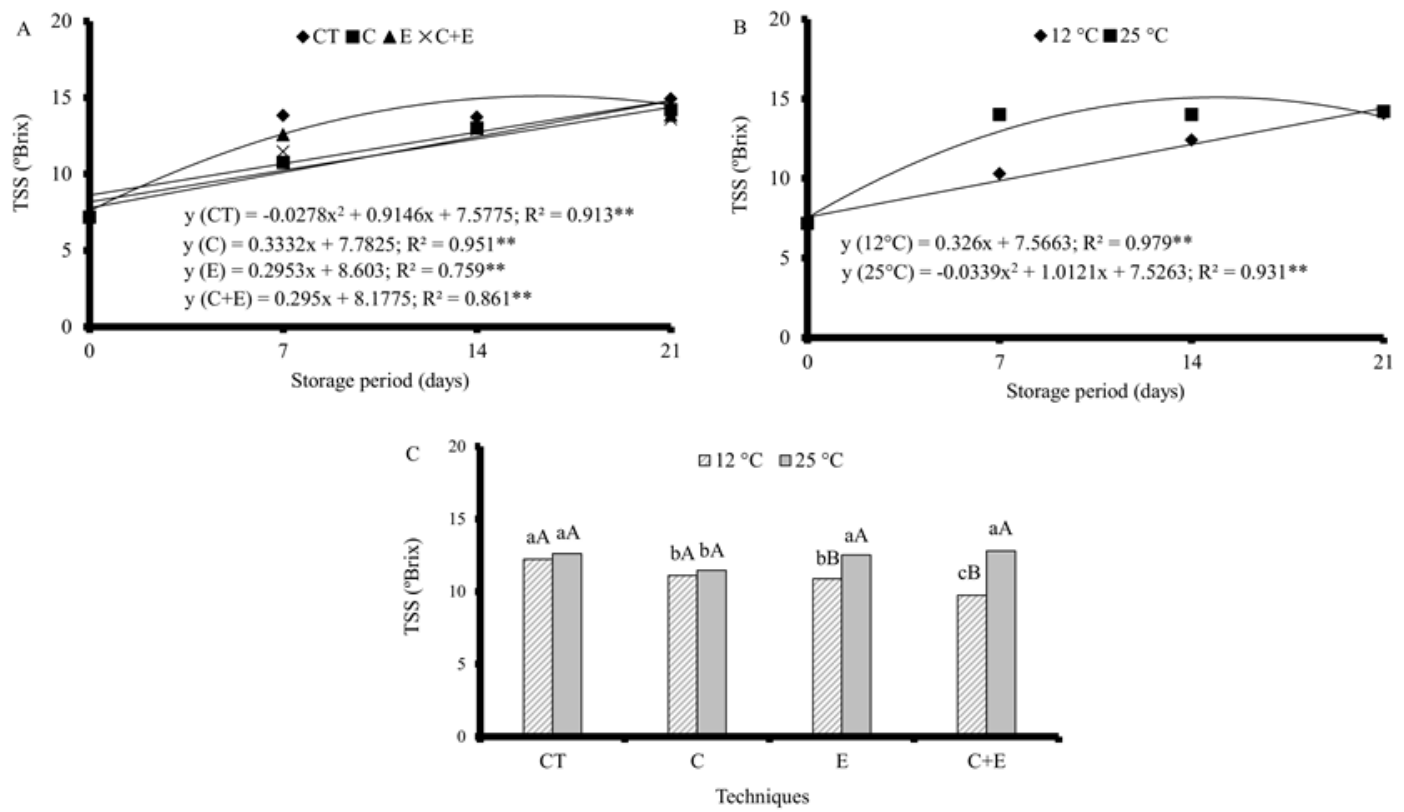

Figure 3. Influence of the interaction between the technique and storage duration (A), storage temperature and storage duration (B), and technique and storage temperature (C) on the total soluble solids (TSS) of 'Tommy Atkins' mangoes. CT - control; C - carnauba wax; E - Xtend packaging; C + E - carnauba wax and Xtend packaging. Bars with the same capital letter in the technique at different temperatures do not differ by Tukey's test at $5 \%$ probability.

This trend in the TSS was also observed by Neves et al. (2008), who found that despite the presence of an ethylene absorber sachet inside low-density polyethylene (LDPE) containers, the 'Tommy Atkins' and 'Haden' mangoes showed an increase in TSS. However, this increase was less rapid than that observed in the current study, due to differences in the storage atmosphere.

The cold temperature storage was effective in slowing down the TSS increase (Figure 3B), particularly with the use of Xtend packaging (E) (13.23 ${ }^{\circ}$ Brix) and carnauba wax plus Xtend packaging $(\mathrm{C}+\mathrm{E})\left(12.58{ }^{\circ} \mathrm{Brix}\right)$ (Figure $\left.3 \mathrm{C}\right)$, at 21-day storage. In contrast, the control fruits presented $15.55{ }^{\circ}$ Brix, under equivalent conditions. According to Jeronimo et al. (2007), mango consumption should occur when the TSS ranges between 11 and $14{ }^{\circ}$ Brix. This shows that the untreated fruit presented the lowest market quality.

'Tommy Atkins' mangoes stored under modified atmospheres, with either cassava starch coating or carnauba wax coating, and kept in polyvinyl chloride plastic or polyethylene packaging by Santos et al. (2011b), exhibited a lower TSS, when compared with those that had been treated hydrothermally. This suggests that the modification of the atmosphere inhibited the respiratory process, causing the maturation process to slow down.

Similar to the TSS, the total TA of the fruit was also influenced by the factors studied (technique, storage temperature, and storage duration) and their interactions (Figure 4). Acidity decreased throughout storage (Figure 4A), probably due to the reduction in organic acids including the predominant citric acid, through fruit respiration and the conversion of the organic acids into sugars (FAASEMA; ALAKALI; ABU, 2014). Likewise, Santos et al. (2010) and Serpa et al. (2014) observed an increase in TSS and a reduction in TA during the ripening of 'Palmer' mangos. Santos et al. (2011a, b) noticed the same trends in studies on post-harvest 'Tommy Atkins' mango conservation, with cassava starch, corn starch, carnauba wax and plastic packaging.

Refrigeration had an important impact on the control of acidity during fruit ripening (Figure 4B). This was verified by Hojo et al. (2009), where refrigerated 'Palmer' mangoes treated with 1-methylcyclopropene presented higher acidity, ranging from approximately $0.6-0.8 \%$ citric acid after 21 days storage, than those exposed to room temperature during storage, concurring with the results found in the present study.

The techniques were analysed separately. The techniques promoted a smaller reduction in organic acids at $25{ }^{\circ} \mathrm{C}$ than under refrigeration. However, at $12{ }^{\circ} \mathrm{C}$, the use of carnauba wax or a combination of wax and Xtend packaging, helped maintain higher citric acid percentages, of 0.82 and $0.84 \%$, respectively than the control or individual techniques. Diniz (2013) verified that the smaller the variance in and the higher the value of TA, at the end of storage, the more efficacious the treatment applied to the fruit. The same author showed that the ripening of 'Tommy Atkins' mangoes was delayed at $14^{\circ} \mathrm{C}$, when a modified atmosphere was used by packaging and coating (carnauba wax) the fruit. 

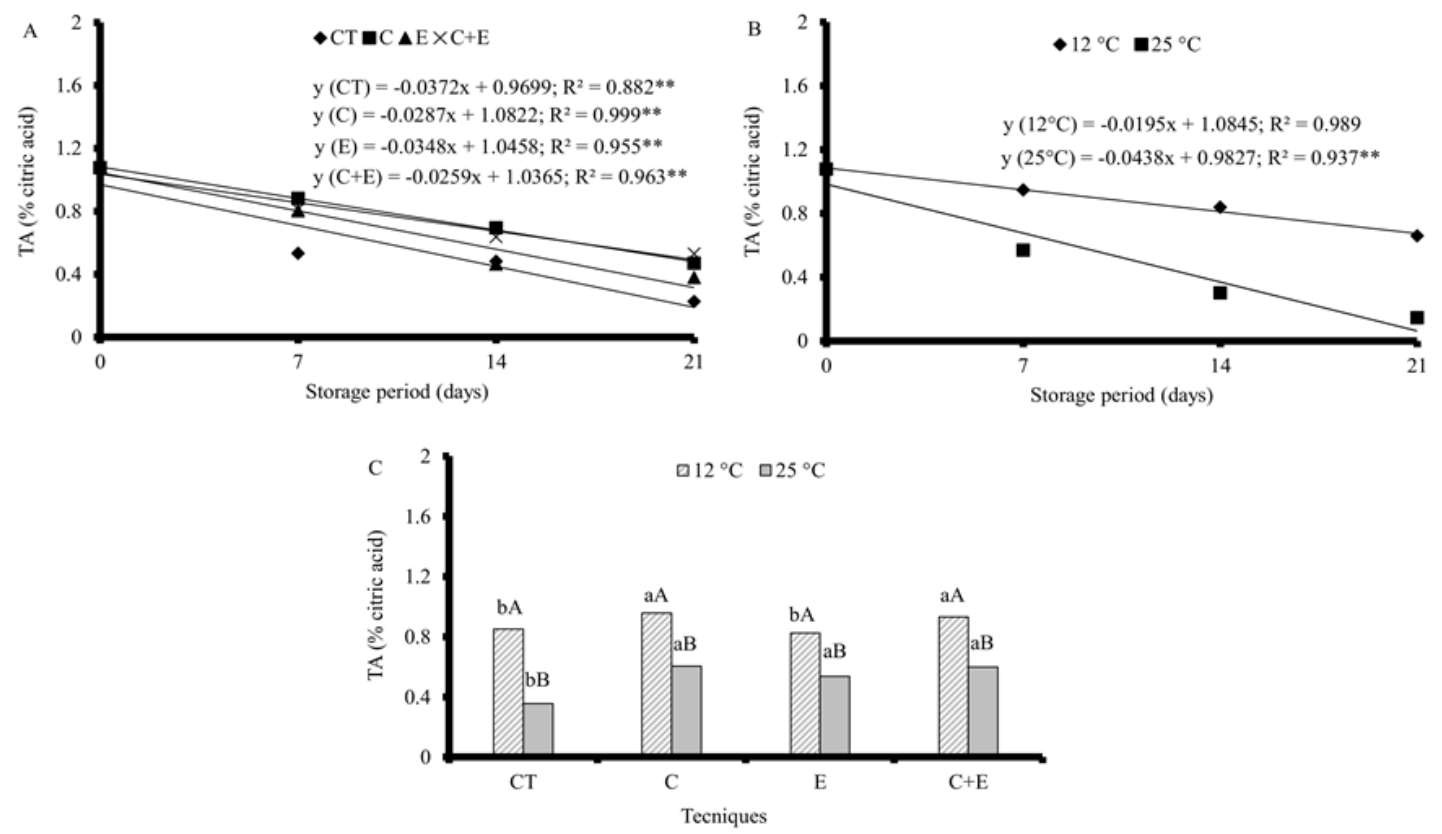

Figure 4. Influence of the interaction between the technique and storage duration (A), storage temperature and storage duration (B), and technique and storage temperature (C) on the titratable acidity (TA) of 'Tommy Atkins' mangoes. CT - control; C - carnauba wax; E - Xtend packaging; C + E - carnauba wax and Xtend packaging. Bars with the same capital letter in the technique at different temperatures do not differ by Tukey's test at $5 \%$ probability.

The vitamin C content, which was $24.5 \mathrm{mg} .100 \mathrm{~g}^{-1}$, decreased by $30-70 \%$ after storage, depending on the technique used (Figure 5A). A similar trend was observed by Jeronimo et al. (2007) during the storage of 'Tommy Atkins' mangoes preserved in various types of packaging. In that study, the initial vitamin $\mathrm{C}$ content (32.37 mg.100 $\mathrm{g}^{-1}$ ) decreased to about $80 \%$ at 16 days of storage. Santos et al. (2010), after storing

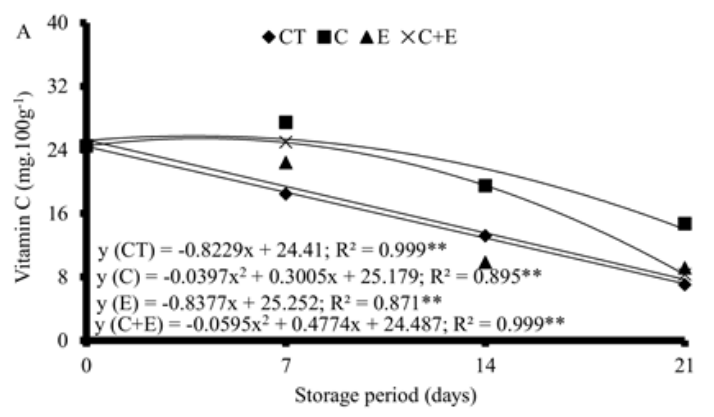

'Palmer' mangoes for 12 days, also observed a reduction in the fruit vitamin $\mathrm{C}$ content, which ranged from 37.27-30.56 mg. $100 \mathrm{~g}^{-1}$. For 'Ubá' mango, Mata et al. (2011) reported a $22.3 \%$ decrease in the vitamin $\mathrm{C}$ content during maturation. The ascorbic acid deterioration observed, irrespective of the fruit variety, is mainly due to oxidation occasioned by the presence of oxygen in the air (CUNHA et al., 2014).

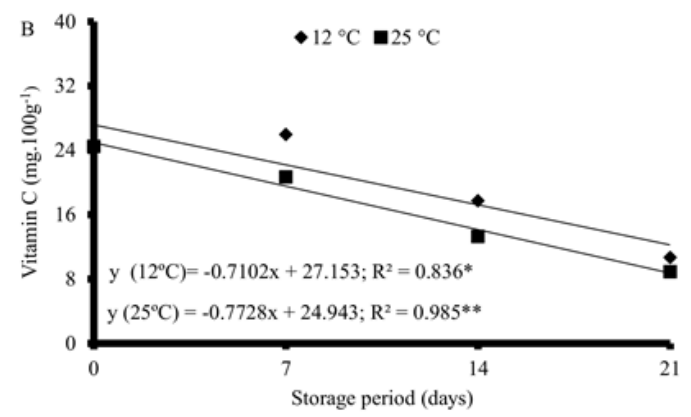

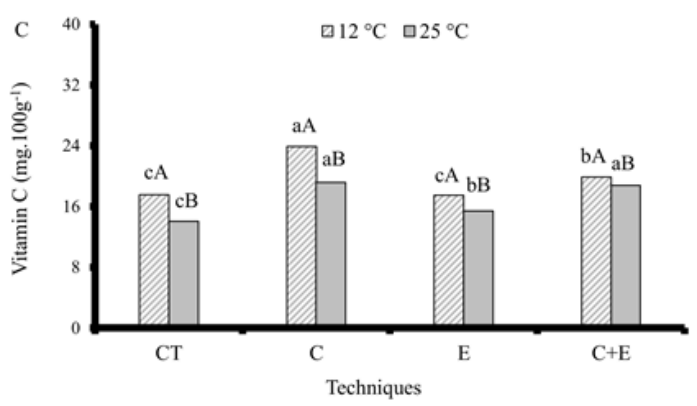

Figure 5. Influence of the interaction between the technique and storage duration (A), storage temperature and storage duration (B), and technique and storage temperature (C) on the vitamin $\mathrm{C}$ content of 'Tommy Atkins' mangoes. CT - control; C - carnauba wax; E - Xtend packaging; C + E - carnauba wax and Xtend packaging. Bars with the same capital letter in the technique at different temperatures do not differ by Tukey's test at $5 \%$ probability. 
Degradation of vitamin $\mathrm{C}$ varied with both the time and temperature of storage. However, storage at $25{ }^{\circ} \mathrm{C}$ caused a greater reduction (Figure 5B) than at $12{ }^{\circ} \mathrm{C}$ because this nutrient is highly unstable in the presence of factors, such as heat and light. The storage atmosphere that resulted in the highest vitamin $\mathrm{C}$ content, was occasioned by the carnauba wax coating, followed by the combination of carnauba wax and Xtend packaging (Figure 5C), both for refrigerated storage. Therefore, the carnauba wax coating and cold storage was the best strategy to minimise degradation of this bioactive compound, and thereby, aid to improve fruit quality. Neves et al. (2008) documented that the post-harvest quality of 'Tommy Atkins' and 'Haden' mangoes packaged in LDPE with an ethylene adsorber, caused the metabolic events to slow down, reducing the natural senescence and preserving the ascorbic acid content of the fruit. Conversely, Serpa et al. (2014) found no effect of cassava starch coatings prepared with clove or cinnamon water, on the vitamin $\mathrm{C}$ content of 'Palmer' mangoes stored at $25{ }^{\circ} \mathrm{C}$ for 10 days.

Chromatographic analysis of the storage atmosphere revealed that fruit coated with carnauba wax and/or Xtend packaging and stored at $12{ }^{\circ} \mathrm{C}$, presented lower $\mathrm{CO}_{2}$ accumulation than the fruits stored at $25{ }^{\circ} \mathrm{C}$, probably because, at the lower temperature, the fruit presented a less rapid respiratory metabolism (Figure 6). The combination of wax, packaging and ambient temperature increased the respiratory rate up to day 14 of storage, which was probably the time limit for the presence of adverse levels of $\mathrm{CO}_{2}$, which would result in the eventual deterioration of the fruit due to the predominant presence of oxidative reactions.

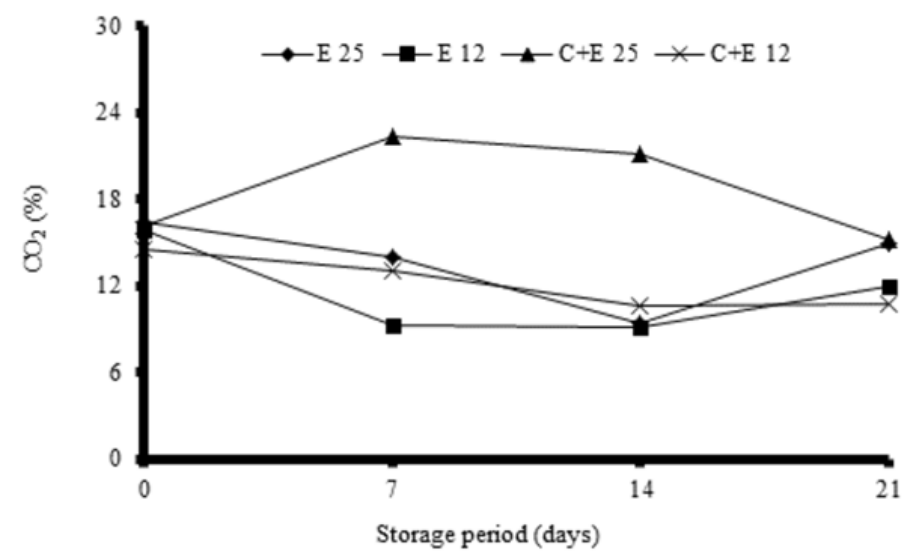

Figure 6. Means and standard deviation of the $\mathrm{CO}_{2}$ percentage in Xtend packaging containing 'Tommy Atkins' mangoes, with and without carnauba wax coating, stored at $12{ }^{\circ} \mathrm{C}(\mathrm{E} 12$ and $\mathrm{C}+\mathrm{E} 12)$ and $25^{\circ} \mathrm{C}(\mathrm{E} 25$ and $\mathrm{C}+\mathrm{E} 25)$ for 21 days. $\mathrm{E}$ - Xtend packaging; $\mathrm{C}+\mathrm{E}$ - carnauba wax and Xtend packaging.

The $\mathrm{CO}_{2}$ concentrations obtained for the various treatments, substantiate the physico-chemical evaluations results found in this work. The results also confirm that modifying the atmosphere was effective for providing the optimal temperature and humidity conditions (RAI; OBEROI; BABOO, 2002). Packaging with plastic films creates a micro-atmosphere around the fruits, reducing the respiration rate and other metabolic reactions (VIEITES et al., 2011). Pinto et al. (2006) observed that the atmosphere modified by plastic films changed the metabolic activity of papaya cv. 'Golden' stored under refrigeration, minimising softening and slowing down the increase in TSS. The accumulation of $\mathrm{CO}_{2}$ in the packages, as verified by the authors, was due to the storage period, the climacteric fruit characteristics and the thickness and diffusivity of the package. In the present study, the fruits packed in LDPE film had an $\mathrm{O}_{2}$ and $\mathrm{CO}_{2}$ diffusivity higher than the Xtend film, which resulted in relative amounts of $\mathrm{CO}_{2}$ of 2.51 and 1.09 , respectively on day 12 of storage. Previously, Ramayya, Niranjan and Duncan (2012) stated that the most effective treatment for 'Alphonso' mangoes stored at $10^{\circ} \mathrm{C}$ for 21 days, was dipping in water maintained at $40{ }^{\circ} \mathrm{C}$ for $40 \mathrm{~min}$, followed by packaging under $50 \% \mathrm{CO}_{2}$ in bags made of unperforated film when compared with mangoes packaged under 25 and $75 \% \mathrm{CO}_{2}$.

\section{CONCLUSIONS}

All variables studied went through alterations during storage of the 'Tommy Atkins' mangoes, due to the influences of the technique, storage temperature and storage duration.

Cold storage slowed down the rate of degradation, which helped conserve 'Tommy Atkins' mangoes.

The use of carnauba wax coating and Xtend packaging made it possible to store 'Tommy Atkins' mangoes at $12 \pm 1{ }^{\circ} \mathrm{C}$ for 21 days, by reducing the concentration of $\mathrm{CO}_{2}$ in the storage atmosphere to preserve desirable characteristics, such as firmness, and decrease mass loss and fruit acidity. 


\section{ACKNOWLEDGEMENTS}

The authors thank the Coordination for the Improvement of Higher Education Personnel (CAPES) for granting the Masters Scholarship; Fundação de Amparo à Pesquisa do Estado da Bahia (FAPESB) and Francisco Vivini from the Farm Special Fruit and Agroservice.

\section{REFERENCES}

AMARIZ, A. et al. Recobrimentos à base de carboximetilcelulose e dextrina em mangas 'Tommy Atkins' armazenada sob refrigeração. Ciência Rural, Santa Maria, v. 40, n. 10, p. 2199-2205, 2010.

ASSIS, O. B. G.; BRITTO, D. Revisão: coberturas comestíveis protetoras em frutas: fundamentos e aplicações. Brazilian Journal of Food Technology, Campinas, v. 17, n. 2, p. 87-97, 2014.

BRITO, L. R. et al. Effect of storage temperature and sanitation form on the quality of 'Tommy Atkins' mangoes produced at in Peixe-Tocantins State. Journal of Biotechnology and Biodiversity, Gurupi, v. 4, n. 1, p. 32-39, 2013.

CHITARRA, M. I. F.; CHITARRA, A. B. Póscolheita de frutos e hortaliças: fisiologia e manuseio. 2. ed. Lavras, MG: UFLA, 2005. 785 p.

CORDEIRO, M. H. M. et al. Conservação póscolheita de manga var. Palmer com uso de 1metilciclopropeno. Magistra, Cruz das Almas, v. 26, n. 2, p. 102-113, 2014.

CUNHA, K. D. et al. Estabilidade de ácido ascórbico em sucos de frutas frescos sob diferentes formas de armazenamento. Brazilian Journal of Food Technology, Campinas, v. 17, n. 2, p. 139-145, 2014.

DINIZ, M. D. M. S. Propriedades texturais, físicoquímicas, reológicas e enzimáticas da manga "Tommy Atkins" durante o armazenamento em atmosfera modificada sob refrigeração. 2013. 159 f. Tese (Doutorado em Engenharia Agrícola: Área de Concentração em Armazenamento e Propriedades Físicas de Produtos Agrícolas) - Universidade Federal de Viçosa, Viçosa, 2013.

FAASEMA, J.; ALAKALI, J. S.; ABU, J. O. Effects of storage temperature on 1-methylcyclopropenetreated mango (Mangnifera indica) fruit varieties. Journal of Food Processing and Preservation, Singapore, v. 38, n. 1, p. 289-295, 2014.
GUADARRAMA, A.; PEÑA, Y. Actividad respiratória vs. Variaciones físicas y químicas en la maduración de frutos de naranjita china (Citrus $x$ microcarpa Bunge). Bioagro, Barquisimeto, v. 25, n. 1, p. 57-63, 2013.

HOJO, E. T. D. et al. Avaliação da qualidade de manga 'Palmer' tratada com 1-metilciclopropeno e armazenada sob refrigeração e condição ambiente. Revista Brasileira de Fruticultura, Jaboticabal, v. 31, n. 1, p. 28-38, 2009.

INSTITUTO ADOLFO LUTZ - IAL. Métodos físico-químicos para análise de alimentos. 4. ed. São Paulo, SP: IAL, 2008. 1020 p.

JERONIMO, E. M. et al. Conservação pós-colheita de mangas 'Tommy Atkins' armazenadas sob atmosfera modificada. Semina: Ciências Agrárias, Londrina, v. 28, n. 3, p. 417-426, 2007.

JHA, S. N.; KINGSLY, A. R. P.; CHOPRA, S. Physical and mechanical properties of mango during growth and storage for determination of maturity. Journal of Food Engineering, Davis, v. 72, n. 1, p. 73-76, 2006.

MATA, G. M. S. C. et al. Teores de $\beta$-caroteno e vitamina $\mathrm{C}$ durante o amadurecimento da manga "Ubá" (Mangifera indica L. var. Ubá). Revista do Instituto Adolfo Lutz, São Paulo, v. 70, n. 2, p. 225229, 2011.

MIGUEL, A. C. A. et al. Qualidade de mangas cv. Palmer após armazenamento sob baixas temperaturas. Revista Brasileira de Fruticultura, Jaboticabal, v. 35, n. 2, p. 398-408, 2013.

MOTA, W. F. et al. Utilização da atmosfera modificada com filme de pvc e cera na conservação pós-colheita de banana 'prata anã'. Magistra, Cruz das Almas, v. 24, n. 2, p. 108-115, 2012.

NEVES, L. C. et al. Qualidade pós-colheita de mangas, não-refrigeradas, e submetidas ao controle da ação do etileno. Revista Brasileira de Fruticultura, Jaboticabal, v. 30, n. 1, p. 94-100, 2008.

PINTO, L. K. A. et al. Influência da atmosfera modificada por filmes plásticos sobrea qualidade do mamão armazenado sob refrigeração. Ciência e Tecnologia de Alimentos, Campinas, v. 26, n. 4, p. 744-748, 2006.

RAI, D. R.; OBEROI, H. S.; BABOO, B. Modified atmosphere packaging and its effect on quality and shelf-life of fruits and vegetables: an overview. Journal of Food Science and Technology, Amritsar, v. 39, n. 3, p. 199-207, 2002. 
RAMAYYA, N.; NIRANJAN, K.; DUNCAN, E. Effects of modified atmosphere packaging on quality of 'Alphonso' mangoes. Journal of Food Science and Technology, Amritsar, v. 49, n. 6, p. 721-728, 2012.

SANTOS, L. O. et al. Conservação e qualidade de mangas 'Palmer' submetidas a tratamento com fungicidas e hidrotérmico. Ciência e Agrotecnologia, Lavras, v. 34, n. 6, p. 1514-1521, 2010 .

SANTOS, A. E. O. et al. Influência de biofilmes de fécula de mandioca e amido de milho na qualidade pós-colheita de mangas 'Tommy Atkins'. Revista Brasileira de Ciências Agrárias, Recife, v. 6, n. 3, p. 508-513, 2011a.

SANTOS, A. E. O. et al. Efeito do tratamento hidrotérmico e diferentes revestimentos na conservação pós-colheita de mangas 'Tommy Atkins'. Revista Brasileira de Ciências Agrárias, Recife, v. 6, n. 1, p. 140-146, 2011 b.

SERPA, M. F. P. et al. Conservação de manga com uso de fécula de mandioca preparada com extrato de cravo e canela. Revista Ceres, Viçosa, v. 61, n. 6, p. 975-982, 2014.

SILVA, F. A. S. ASSISTAT Software: Assistência Estatística. Versão 7.7 beta. 2014.

STROHECKER, R.; HENNING, H. M. Análisis de vitaminas: métodos comprobados. Madrid: Paz Montalvo, 1967. $428 \mathrm{p}$.

VIEITES, R. L. et al. Caracterização físico-química, bioquímica e funcional da jabuticaba armazenada sob diferentes temperaturas. Revista Brasileira de Fruticultura, Jaboticabal, v. 33, n. 2, p. 362-375, 2011.

VILAS BOAS, B. M. et al. Avaliação da qualidade de mangas 'Tommy Atkins' minimamente processadas. Revista Brasileira de Fruticultura, Jaboticabal, v. 26, n. 3, p. 540-543, 2004.

YAMASHITA, F. et al. Embalagem individual de mangas cv. 'Tommy Atkins' em filme plástico: efeito sobre a vida de prateleira. Revista Brasileira de Fruticultura, Jaboticabal, v. 23, n. 2, p. 288-292, 2001 . 